\title{
Assessment of Industrial Influent and Effluent Water Quality at a Bottling Company in Aba, Abia State, Nigeria
}

\author{
Ochor N. O. ${ }^{1}$, Onyeizu R. U. ${ }^{2}$, Uchendu U. I. ${ }^{2}$ and Ikpeazu O. V. ${ }^{3}$ \\ ${ }^{1}$ Department of Forestry and Environmental Management, Michael Okpara University of Agriculture, Umudike, \\ Abia State, Nigeria \\ ${ }^{2}$ Department of Environmental Management and Toxicology, Michael Okpara University of Agriculture, \\ Umudike, Abia State, Nigeria \\ ${ }^{3}$ Department of Biochemistry, Abia State University, Uturu, Abia State, Nigeria \\ Corresponding Author:*uchendu.udochukwuka@mouau.edu.ng
}

https://doi.org/10.36263/nijest.2020.02.0200

\begin{abstract}
This study assessed water sources (treated water, pond water and harvested rain water) and effluents discharged from a bottling company in Aba, Abia State. A single factor experiment in randomized complete block designs with three replications was used to assess the physicochemical properties of water at various sources. The result shows that pond water and rain water gave significantly the highest and least $N$ and $P$ contents respectively ( $N$ : 33.60-5.60 mg/l; P: 12.40$10.30 \mathrm{mg} / \mathrm{l})$. The $K$ contents of the various water point sources were significantly higher as follows: pond water > effluent water > rain water > treated water $(6.50>0.30>0.20>0.20)$. Pond water was statistically highest in Mg contents when compared to other sources. The Fe contents were significantly higher as follows: effluent water > rain water > treated water > pond water, while Fe content in pond water wasn't significantly higher when compared to its content in rain water. Pond water and treated water were significantly the highest and least $(P \leq 0.05)$ in organic matter $(O M)$ and organic carbon $(O C)$ contents respectively. No significant differences existed between colour intensity and turbidity values of the various water point sources. Effluent water from the industry and pond water were significantly the least in DO values respectively. Rain water and pond water were significantly the least in BOD concentrations. Effluent water was significantly the highest in TSS values, while the least TSS values were significantly recorded for treated water and rain water.
\end{abstract}

Keywords: Bottling company, Effluent, Nutrients, Wastewater, Water sources

\subsection{Introduction}

According to Chennakrishnan et al. (2008), the availability and quality of water have always played an important role in determining the quality of life. Water quality is closely linked to water use and to the state of economic development. Halim et al. (2018) reported that over the last years, in many African countries a considerable population growth has taken place, accompanied by a steep increase in urbanization, industrial and agricultural land use. This has entailed a tremendous increase in discharge of a wide variety of pollutants to receiving water bodies and has caused undesirable effects on the different components of the aquatic environment and on fisheries (Amah-Jerry et al., 2017). This has led to a growing appreciation that nationally, regionally, and globally, the management and utilization of natural resources should be improved and that the amount of waste and pollution generated by human activity need to be reduced on a large scale (Anyanwu and Nwigwe, 2015).

Industries are the major sources of pollution in the environments. Based on the type of industry, various levels of pollutants can be discharged into the environment directly or indirectly through public sewer lines (Anyanwu and Ihediwah, 2015). Wastewater from industries includes employees' sanitary waste, process wastes from manufacturing, wash waters and relatively uncontaminated water from heating and cooling operations (Kanu and Achi, 2011). High levels of pollutants in river water systems causes an increase in biological oxygen demand (BOD), chemical oxygen demand (COD), total dissolved solids (TDS), total suspended solids (TSS), toxic metals such as $\mathrm{Cd}, \mathrm{Cr}, \mathrm{Ni}$ and $\mathrm{Pb}$ and 
faecal coliform and hence make such water unsuitable for drinking, irrigation and aquatic life. Industrial wastewaters range from high biochemical oxygen demand (BOD) from biodegradable wastes such as those from human sewage, pulp and paper industries, slaughter houses, tanneries and chemical industry. Others include those from textiles, which may be toxic and require on-site physiochemical pre-treatment before discharge into municipal sewage system (Anyanwu and Ihediwah, 2015).

The pollution of water bodies is a major concern, firstly because of increasing utilization for human needs and secondly because of the ill effects of the increased industrial activity (Jain et al., 2005). Nwankwo et al. (2014) noted that anthropogenic sources of contaminants are contributed from agriculture, domestic and industrial wastes. Nutrient concentrations in streams and rivers have been strongly correlated with human land use and disturbance gradients. Both $\mathrm{N}$ and $\mathrm{P}$ enrichment have links with the agricultural and urban land uses in the watershed (Dawood, 2017).

Sarker et al. (2013) reported that majority of manufactures are water based and a considerable volume of effluent is ejected to the environment either treated or untreated leading to the problem of surface and ground water pollution. Similarly, Nnamani et al. (2015) reported that the changes in the nutrient concentrations of water may lead to harmful effects to humans and aquatic life. Most heavy metals in streams are commonly associated with industrial discharges and most heavy metals common in industrial effluents have cumulative toxins to aquatic life. The natural water systems have been polluted by different sources such as leakage and spills at industries, improper hazardous waste disposal, improper use and disposal of pesticides, leachate from landfills, septic systems, saline intrusion, fertilizers, animal wastes, leaking underground storage tanks, pipeline breaks (Kale, 2016). The pollutants coming as a waste to water bodies are creating nuisance by way of physical appearance, odour, taste, quality and render the water harmful for utility. Thus, the aim of this study was to assess water sources (treated water, pond water and rain water) and effluents discharge from a bottling company in Aba, Abia State.

\subsection{Methodology}

\subsection{Study area}

The research was carried out in Aba, Abia state in south eastern Nigeria. Aba is located on longitude $07^{\circ} 33^{\prime} \mathrm{N}$ and latitude $05^{\circ} 29^{\prime} \mathrm{E}$ on an altitude of a hundred and twenty-two meters (122m), and within the tropical humid rainforest (Amah-Jerry et al., 2017; Keay, 1959). It has the following mean annual climatic data: rainfall $2300 \mathrm{~mm}$, with the rainy season between March and November and the dry season starting from December and ending in February/March; minimum and maximum temperatures of $22^{\circ} \mathrm{C}$ and $31^{\circ} \mathrm{C}$ respectively; relative humidity of $60-80 \%$. Aba has two local government areas: Aba North and Aba South LGAs with an estimated population of 534,265 based on the 2006 population census (NPC, 2006).

\subsection{Sample collection}

Water samples were collected from four different point sources which include: the effluent waste water discharge from the industry, the pond water $100 \mathrm{~m}$ away from the effluent waste discharge source, rain water harvested within the bottling company and treated water obtained from the borehole of the company. The samples collected were taken to the Soil Laboratory Unit of National Root Crops Research Institute (NRCRI) Umudike, Abia State for physicochemical analyses.

\subsection{Laboratory analyses}

Total Nitrogen $(\mathrm{N})$ was determined by semi-micro distillation method, using the Marklian Kjedahl apparatus (Bremmer and Mulvany, 1982). Potassium (K) and Sodium (Na) were determined by direct reading with the flaming emission Photometer (Black, 1965). Calcium (C) and Magnesium (Mg) were determined using the Ethylene Diaminetetracetic acid (EDTA) Vassante Complexometric titration method (Allison, 1973). Chlorine $(\mathrm{Cl})$ was determined titrimetrically (Dewis and Freitas, 1970). Sulphate $\left(\mathrm{SO}_{4}\right)$ was determined using the gravimetric method (APHA, 1995). Phosphorus (P) was determined by the Vanando - molybdate yellow method using the spectrophotometer (Bray and Kurtz, 1945). Hydrogen ion concentration $(\mathrm{pH})$ was measured electronically on a direct $\mathrm{pH}$ meter, using a glass electrode with a saturated potassium chloride-calomel reference electrode (Dewis and 
Freitas, 1970). Colour intensity was measured by visual comparison with platinum-cobalt standard which is unit of colour being produced by $1 \mathrm{mg} / \mathrm{l}$ platinum in the form of chrophinate ions (Uchegbu, 1998). Turbidity was determined with the Jackson Candle Turbidimeter (Uchegbu, 1998). Organic carbon and organic matter were determined by wet-acid oxidation using the Walkley and Black method (Allison, 1973). Total Suspended Solids (TSS) was determined using a gooch crucible. Dissolved Oxygen (DO) was determined using the standard Winker's method according to Wetzel and Likens (1979). Biological Oxygen Demand (BOD) was estimated using the 5 days incubation method as described by APHA (1995). Iron (Fe) was determined using the Atomic Absorption Spectrophotometer (AAS) method with UNICAM 929 Spectrophotometer equipment. To maintain the integrity of the water samples, physicochemical parameters sensitive to environmental changes such as $\mathrm{pH}$ was recorded in-situ. The samples were later transported to the laboratory in an ice chest for further analysis. Student's t-test at $\mathrm{P} \leq 0.05$ was used to determine the differences between the physico-chemical properties of the industry's waste water. The values obtained from the analyses were compared with World Health Organization (WHO) standard.

\subsection{Results and Discussion}

The results of the findings are presented in Table 1 indicating the nutrient contents in various water source treatments and Table 2 summarizing the colour intensity, turbidity, $\mathrm{SO}_{4}$, Dissolved Oxygen (DO) after 5 days, Biological Oxygen Demand (BOD) and Total Suspended Solids (TSS) of various water/liquid source treatments.

Table 1: Nutrient contents of various water/liquid sources at a bottling company in Aba, Nigeria

\begin{tabular}{|c|c|c|c|c|c|c|c|c|c|c|}
\hline $\begin{array}{l}\text { Water } \\
\text { Sources }\end{array}$ & $\mathrm{N}$ & $\mathrm{P}$ & $\mathrm{K}$ & $\mathrm{Na}$ & $\mathrm{Ca}$ & $\mathrm{Mg}$ & $\mathrm{Fe}$ & $\mathrm{Cl}$ & $\begin{array}{l}\text { Org } \\
\text { Matter } \\
(\%)\end{array}$ & $\begin{array}{l}\text { Org } \\
(\%)\end{array}$ \\
\hline $\begin{array}{l}\text { Treated } \\
\text { Water }\end{array}$ & 11.20 & 10.70 & 0.20 & 0.20 & 16.03 & 4.86 & 3.54 & 56.80 & 0.04 & 0.02 \\
\hline Pond Water & 33.60 & 12.40 & 6.50 & 1.60 & 72.14 & 19.45 & 2.74 & 95.85 & 0.23 & 0.13 \\
\hline Effluents & 8.40 & 10.70 & 0.30 & 7.90 & 20.04 & 4.86 & 3.86 & 181.05 & 0.11 & 0.06 \\
\hline Rain Water & 5.60 & 10.30 & 0.20 & 0.40 & 24.05 & 9.72 & 3.42 & 24.85 & 0.07 & 0.04 \\
\hline $\begin{array}{l}\mathrm{F}- \\
(0.05)\end{array}$ & 0.33 & 0.12 & 0.18 & 0.14 & 0.06 & 0.15 & 0.06 & 4.53 & 0.01 & 0.01 \\
\hline
\end{tabular}

Table 2: Colour intensity, turbidity, $\mathrm{SO}_{4}, \mathrm{DO}, \mathrm{BOD}_{5}$ and TSS of various water/liquid sources at a bottling company in Aba, Nigeria

\begin{tabular}{|c|c|c|c|c|c|c|c|}
\hline Water Sources & $\begin{array}{l}\text { Colour } \\
\text { Intensity }\end{array}$ & Turbidity & $\mathrm{SO}_{4}(\mathrm{mg} / \mathrm{l})$ & $\mathrm{DO}(\mathrm{mg} / \mathrm{l})$ & $\begin{array}{ll}\text { DO } \\
(\mathrm{mg} / \mathrm{l})\end{array}$ & BOD (mg/1) & TSS \% \\
\hline Treated Water & 0.006 & 0.010 & 30.00 & 1568.60 & 2778.96 & 1210.40 & 0.22 \\
\hline Pond Water & 0.007 & 0.011 & 20.00 & 2196.10 & 2947.40 & 751.30 & 6.72 \\
\hline Effluents & 0.011 & 0.013 & 50.50 & 3607.83 & 4800.03 & 1192.17 & 40.88 \\
\hline Rain Water & 0.002 & 0.007 & 30.50 & 1019.60 & 2610.54 & 1590.90 & 0.16 \\
\hline $\begin{array}{l}\mathrm{F}-\mathrm{LSD} \\
(0.05)\end{array}$ & NS & NS & 1.77 & 99.60 & 6.70 & 4.42 & 1.98 \\
\hline
\end{tabular}

Pond water was significantly the highest in $\mathrm{N}$ content while rainwater had the least $(\mathrm{P} \leq 0.05)$ in $\mathrm{N}$ content. Treated water was significantly higher in $\mathrm{N}$ contents when compared to other water sources are summarized as follows: pond water $>$ treated water $>$ effluent water $>$ rain water. In terms of $P$ contents, pond water was significantly the highest in $\mathrm{P}$ content while the rainwater gave the least $(\mathrm{P} \leq$ 0.05 ) in $\mathrm{P}$ content. However, no significant differences existed between the $\mathrm{P}$ contents of pond water and effluent water. Pond water again gave significantly the highest in $\mathrm{K}$ content while the statistically similar $\mathrm{K}$ contents of treated water and rain water had the least $\mathrm{K}$ contents. The $\mathrm{K}$ contents of the water source treatments are in the following significant order: pond water > treated water $>$ effluent water $>$ rain water. The Na contents of the various water source treatments are in the following order $(\mathrm{P} \leq 0.05)$ : effluent water $>$ pond water $>$ rain water $>$ treated water. Thus, effluent water gave significantly the highest and least $\mathrm{Na}$ contents. Pond water had the highest $(\mathrm{P} \leq 0.05) \mathrm{Ca}$ contents, while treated water gave the least $\mathrm{Ca}$ content. The overall results of the $\mathrm{Ca}$ contents of the different water source treatments are significantly as follows: pond water > rain water > effluent water > 
treated water. The $\mathrm{Mg}$ contents of the various water sources are as follows $(\mathrm{P} \leq 0.05)$ : pond water $>$ rain water $>$ effluent water $=$ treated water. Thus, pond water had statistically the highest Mg contents while the similar $(\mathrm{P} \leq 0.05) \mathrm{Mg}$ contents of effluent water and treated water gave significantly the least $\mathrm{Mg}$ values. Effluent water, followed by treated water gave significantly higher Fe contents than pond water and rain water which had statistically similar Fe contents. The summary of the Fe contents are statistically as follows: effluent water > treated water > pond water > rain water. The $\mathrm{Cl}$ contents in the different water sources were significantly as follows: effluent water $>$ pond water $>$ treated water > rain water, thus, effluent water and rain water gave significantly the highest and least $\mathrm{Cl}$ contents.

The higher $\mathrm{Na}, \mathrm{SO}_{4}, \mathrm{Fe}$ and $\mathrm{Cl}$ in the effluent could be as a result of excessive use of and/or constant accumulation of chemicals used in production. It could also be as a result of excessive use of the nonbiodegradable nature of these chemicals, and the detergents used for washing and cleaning the various plants used in production and the floors of the production units. Another reason could be the characteristic feature of the drainage basin compared to those of the other point sources (Isirimah, 2002). The pond water has high $\mathrm{K}, \mathrm{Mg}, \mathrm{Ca}, \mathrm{PO}_{4}$, and $\mathrm{N}$ contents compared with the set standards of FEPA (1991) and SON (2007). The low nutrient contents on the other point sources indicate that there may be little or no chemical pollutants present in them. Pond water had significantly the highest Organic Matter (OM) and Organic Carbon (OC) contents, while treated water had the least $(\mathrm{P} \leq 0.05)$ values. The overall results of the $\mathrm{OM}$ and $\mathrm{OC}$ contents of the various water sources. The relatively high organic carbon $(\mathrm{OC})$ and organic matter $(\mathrm{OM})$ contents of the pond water source as against the other point sources, it could be due to the decayed/decaying biodegradable materials (leaf litter, etc.), time as noted by Nwankwo et al. (2014).

Effluents and rain water gave significantly the highest and the least DO (immediately analysed) and DO (after 5 days storage) respectively. The overall results of the $\mathrm{DO}_{5}$ of the various treatments were statistically as follows; effluents > pond water > treated water > rain water. The results of the BOD in the liquid treatments were significantly as follows: rain water $>$ treated water $>$ effluents $>$ pond water. Thus, rainwater and pond water respectively had the highest and least $(\mathrm{P} \leq 0.05)$ concentrations of BOD. The increasing/high $\mathrm{DO}$ and $\mathrm{BOD}_{5}$ contents of water obtained in effluents could be due to the increased use of factory chemicals in production which are daily disposed off into the same channel that of rainfall, and mineral salt which corresponding decrease biochemical processes of catabolism and anabolism as observed by Kale (2016). There are no limit saturations for DO and $\mathrm{BOD}_{5}$. Concentrations of TSS in the liquid treatments were in the following order $(\mathrm{P} \leq 0.05)$ : effluents $>$ pond water $>$ treated water $=$ rain water. The higher the total solids in the effluent source $(40.88)$ and pond water source (6.72) within the factory could be due to the presence of high organic matter and chemical contents in these point sources respectively. This is in tandem with Nnamani et al. (2015) which stated that effluents might also contain chlorides, cyanides, sulphur compounds, detergents, oil and grease, and nitrate compounds which increase the amount of total solids contained therein. Effluents from the factory had significantly higher $\mathrm{pH}(8.25)$ than all the other point sampling sources. This could be due to the effects of the raw materials used for production of soft drinks and waste water from washing (with detergents) the different plants used for production.

Generally, the $\mathrm{pH}$ at all point sources ranged from 5.79 in the factory's treatment water point source to 8.25 in the effluent point source. This range is close to the permissible limits of 6.5 minimum to 8.5 maximum for drinking water and other domestic uses (SON, 2007; WHO, 1984). Sarker et al. (2013) noted that $\mathrm{pH}$ is an important factor that regulates chemical and biochemical processes in natural wastes and living things. However, Dawood (2017) observed that $\mathrm{pH}$ outside the permissible limits has no adverse health impact. $\mathrm{pH}$ range at the various point sources is close to the permissible limit for aquatic life $(6.0-9.0)$. For colour intensity (platinum cobalt units), higher and lower colour values indicate traces of colloidal particles in the various point sources. The various water colour values of the point sources: Effluents (0.011), pond water (0.007), factory treated water (0.006), and rainwater (0.002), are all within the permissible limit of $15 \mathrm{pc}$ units (Halim et al., 2018). For turbidity (Jackson turbidity units), the higher the turbidity value, the less turbid and clearer the water is. The higher turbidity value of effluents $(0.013)$ compared to that of rainfall (0.007) could be due to scouring of materials at root tops and addition of surface run-off (Phiri et al., 2005). These reasons are similar to those of Ani et al. (2016) and Amah-Jerry et al. (2017). The similar higher turbidity values of the effluents $(0.013)$, pond water $(0.011)$ and factory treated water $(0.10)$ compared to rain water $(0.007)$ 
point sources could be due to decreasing particulate load as a result of sedimentation of slow water flow regimen. The various turbidity values are quite below the maximum desirable limit for drinking water and aquatic life (Anyanwu and Ihediwah, 2015; FEPA, 1991).

\subsection{Conclusions}

This study evaluated the physicochemical assessment of water sources and effluent discharged from a bottling company at Aba. It showed that the effluents from the factory negatively affect drinking water supplies and cause loss of aquatic flora and fauna. Poor funding of the Abia State Environmental Protection Agency, lack of equipment, inadequate manpower, and poor implementation of existing laws on appropriate environmental management are some of the factors that also contribute to negative increase in the impact of industrial effluents on water sources. This study therefore recommends that effluents from industries should be thoroughly treated before they are released into water bodies. Further research should be carried out on water pollution potentials of industries in Aba and other cities in Abia State, Nigeria. The impact of industrial and municipal wastes, especially effluents on public health should also be studied.

\section{References}

Allison, F. E. (1973). Soil Organic Matter and its role in Crop Production. Elsevier Publications. New York, USA.

Amah-Jerry, E. B, Anyanwu, E. D and Avoaja, D. A. (2017) Anthropogenic Impacts on the water quality of Aba River, South, East Nigeria. Ethiopian Journal of Environmental Studies and Management, 10(3), pp. 299- 314.

American Public Health Association (APHA) (1995). Standard Methods for Examination of Water and Waste Waters. $18^{\text {th }}$ Edition. Washington D.C.

Ani, C., Okogwu, O. I., Nwonumara, G. N., Nwani, C. D. and Nwiniyimagu, A. J. (2016). Evaluation of Physicochemical parameters of Selected Rivers in Ebonyi State, Southeast, Nigeria. Greener Journal of Biological Sciences, 6(2), pp. 34-41.

Anyanwu, E. D. and Nwigwe, N. C. (2015). Assessment of Bottled Water Quality Using PhysicoChemical Indicators. Applied Science Research Journal, 3(1), pp. 1-12.

Anyanwu, E. D. and Ihediwah, S. U. (2015). Drinking Water Quality Assessment of Iyinna Spring, Umuariaga, Ikwuano Local Government Area, Abia State. Journal of Aquatic sciences, 30(2), pp. 317-328.

Black, C. A. (Ed) (1965). Methods of Soil Analysis. Vol. 2. Agronomy 9. American Society of Agronomy, Madison, Wisconsin.

Bray, R. H. and Kurtz, L. T. (1945). Determination of Total Organic and Available Forms of Phosphorous. Soil Science, 59, pp. 39-45.

Bremmer, J. M. and Mulvany, C. S. (1982). Total Nitrogen. In: Methods of Soil Analysis, Part 2. Agronomy Monograph No. 9, American Society of Agronomy, Madison, Wisconsin.

Chennakrishnan, C., Stephen, A., Manju, T. and Raveen, R. (2008). Water Quality status of three vulnerable freshwater Lakes of Suburban Chennai, India. Ind. J. Environ. Ecoplan, 15(3), pp. 591596.

Dawood, A. S. (2017). Using of Nemerow's Pollution Index (NPI) for Water Quality Assessment of Some Basrah Marshes, South of Iraq. Journal of Babylon University/Engineering Sciences, 25(5), pp. 1708-1720. 
Dewis, J. and Freitas, F. (1970). Physical and Chemical Method of Soils and Water Analysis. Soils Bulletin: Food and Agriculture Organization of the United Nations. Rome 1970. X + 275 pp.

FEPA, (1991). Guidelines and Standard for Environmental Control in Nigeria, Lagos.

Halim, A., Sharmin, S., Rahman, H., Haque, M., Rahman, S., et al. (2018). Assessment of water quality parameters in baor environment, Bangladesh: A review. International Journal of Fisheries and Aquatic Studies, 6(2), pp. 269- 263.

Isirimah, N. O. (2002). Understanding the Nature, Properties and Sources of Water for Quality Environment. Tom and Harry Publications Ltd, Port Harcourt, Nigeria. 207 pp.

Jain, P., Sharma, J. D., Sohu, D., Sharma, P. (2005). Chemical analysis of drinking water of villages of sanganer Tehsil, Jaipur district. Int. J. Env. Sci. Technol., 2(4), pp. 373-379.

Kale, V. S. (2016). Consequence of Temperature, pH, Turbidity and Dissolved Oxygen Water Quality Parameters. International Advanced Research Journal in Science, Engineering and Technology, 3(8), pp. 186-190.

Kanu, I. and Achi, O. K. (2011). Industrial effluents and their impact on water quality of receiving rivers in Nigeria. Journal of Appl Tech in Env San., 1, pp. 75-86.

Keay, R. W. J. (1959). An Outline of Nigerian Vegetation (2nd edn). Government Printer, Lagos, Nigeria: $46 \mathrm{pp}$.

Nnamani, E. V., Akpagu, F. C. and Eze, C. G. I. (2015). The Analysis of Selected Physico-Chemical Parameters of Water (A Case Study of ISU and Calabar Rivers in Ebonyi State, Nigeria). IOSR Journal of Applied Chemistry, 8(1), pp. 21-25

NPC (2006). National Population Census in Nigeria. National Population Commission, Abuja, Nigeria.

Nwankwo, C., Mohammed, A., Ikyereve, E. R. and Dawari, B. K. (2014). The Impact of human Water Exploitation of Physicochemical characteristics of Mmubete River in the Niger Delta, Nigeria. International Journal of Science and Technology, 3(5), pp. 292-297.

Phiri, O., Mumba, P., Moyo, B. H. Z. and Kadewa, W. (2005). Assessment of the impact of industrial effluents on water quality of receiving rivers in urban areas of Malawi. Int. J. Environ. Sci. Tech., 2, pp. 237-244.

Qadeer, R. (2004). Pollution in drinking water: Their sources, harmful effects and removal procedures. J. Chem. Soc. Pakistan, 26, pp. 293- 301.

Sarker, B. C., Basak, B., Islam, M. S. (2013). Chromium effects of tannery waste water and appraisal of toxicity strength reduction and alternative treatment. International Journal of Agronomy and Agricultural Research, 3(11), pp. 23-35.

SON (Standards Organization of Nigeria) (2007). Standards for drinking water quality. Retrieved from www.unicef.org/nigeria/ng publications. Nigerian Standard for Drinking Water Quality.pdf. Assessed on $12^{\text {th }}$ December, 2018.

Uchegbu, S. N. (1998). Environmental Management and Protection. Precision Printers and Publishers Enugu, Nigeria. ISBN: 978-31943-7-2.

Wetzel, R. G. and Likens, G. E. (1979). Limnological Analysis. W. B. Saunders Ltd. Philadelphia, USA. 
World Bank Report (WHO) (1984). Water Supply and water Disposal: Poverty and Basic Needs. Report of Seminar on Water Quality in Developing Countries of West Africa, Ariwa Hall, Kaduna, Nigeria.

Cite this article as:

Ochor N. O., Onyeizu R. U., Uchendu U. I. and Ikpeazu O. V., 2020. Assessment of Industrial Influent and Effluent Water Quality at a Bottling Company in Aba, Abia State, Nigeria. Nigerian Journal of Environmental Sciences and Technology, 4(2), pp. 253-259. https://doi.org/10.36263/nijest.2020.02.0200 